owing to the variation of the bases of calculation. In chemical works in the United States tables will be found in use:

\begin{tabular}{|c|c|c|c|}
\hline $\begin{array}{l}\text { For weights. } \\
\text { Avoirdupois, }\end{array}$ & $\begin{array}{c}\text { For measures. } \\
\text { English gallons, }\end{array}$ & $\begin{array}{l}\text { For specific gravity. } \\
\text { Beaumé scale, }\end{array}$ & $\begin{array}{l}\text { For temperature. } \\
\text { Fahrenheit scale, }\end{array}$ \\
\hline Apothecary, & Wine " & Twaddle " & Celsius \\
\hline $\begin{array}{l}\text { Troy, } \\
\text { Metric, as kilo- }\end{array}$ & Metric, as liters. & & $\begin{array}{l}\text { Reaumur } \\
\text { Centigrade }\end{array}$ \\
\hline
\end{tabular}

Growing out of these different guides we have endless diffculties unless the writer on a given subject succinctly states by which of the various standards he is governed.

The scale of Beaumé is rendered confusing at times owing to the difference of the modulus that is accepted.

The transmutation of one thermometric scale into another is daily necessary, while errors are frequently made by the difference in the gallon capacity in cubic inches.

The present is opportune for the discussion of this subject with the view of arriving at some deliberate attempt to produce conformity out of this bedlam of figures. The tower of Babel with its traditional confusion of tongues may be taken as representing the difficulties arising in chemical work and transactions. A committee consisting of representatives from each nation could be appointed whose duty it should be to formulate an international system of figures and tables.

Uniform methods and statements for these basal calculations would inure to the ease of commercial transactions throughout the world.

\title{
NOTE ON THE MANUFACTURE OF THE PRUSSIATES.
}

BY WALTER D. Field.

Received October 24,8893 .

IN many branches technical literature is very incomplete. Descriptions of apparatus for the purpose of carrying on technical operations are reproduced in publication after publication. Authors are seemingly forgetful of the fact that the patents of this country represent in a large measure the progress of the various chemical industries.

In the "Fabrikation chemischer Producte aus thierische 
Abfällen." by Hugo Fleck on pages 96 and 99 the same cut is given twice, and as if this were not quite enough to satisfy any one, the same cuts are reproduced in the fifth edition of GrahanOtto. Again in Thorpe's "Dictionary of Applied Chenistry they are repeated. Before Graham (Otto was issued, Henry Bower received a patent (t. S. P... $\therefore$. 210.096 ) for an apparatus that was an improrement on the old forms given in the Crerman technical literature. His invention should have received at least a mention.

In the manufacture of potassium ferrocyanicle, the iron is mostly obtained at the expense of the material of the melting

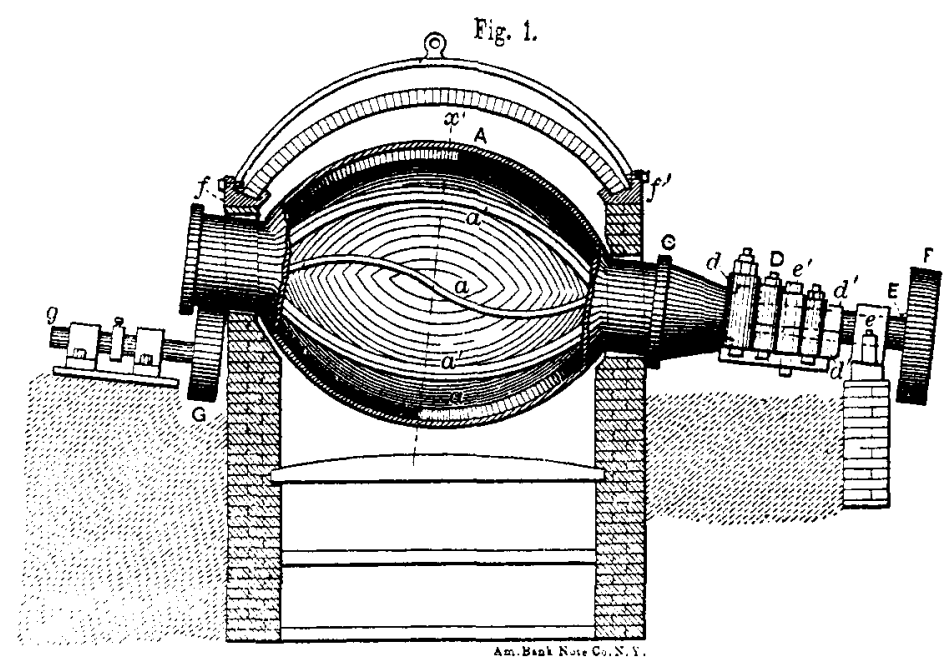

pot. A glance at the cuts given by Hugo Fleck will at once show the great loss of material and the expense involved in the renewal of the melting pots, the tearing down of the masonry, the resetting of the new pot, etc., etc. The life of the pots is very short at the best, and hence it is very desirable that they be used as long as possible without renewal and that they be easily set and unset.

In the apparatus represented by Hugo Fleck in Figures 29 and 30 there would be an abnormal waste of iron. The melt would consume the iron in the lower part, the part with which 
it came in contact, and the remainder of the pot would be a complete loss. If the casting directly over the fire were increased in thickness so as to compensate for the loss of the iron in the melt, the retort would be heated unevenly and a proper condition of the melt could not be maintained.

Bower's apparatus was an improvement on the old forms in many ways, but still he did not reach the best possible results. In 1885 Carhuff received his patent, (No. 310,376 ,) in which his revolving furnace provides for the greatest consumption of the iron in the retort, and also makes it possible to maintain an equal temperature on all parts of the melt. The retort is easily

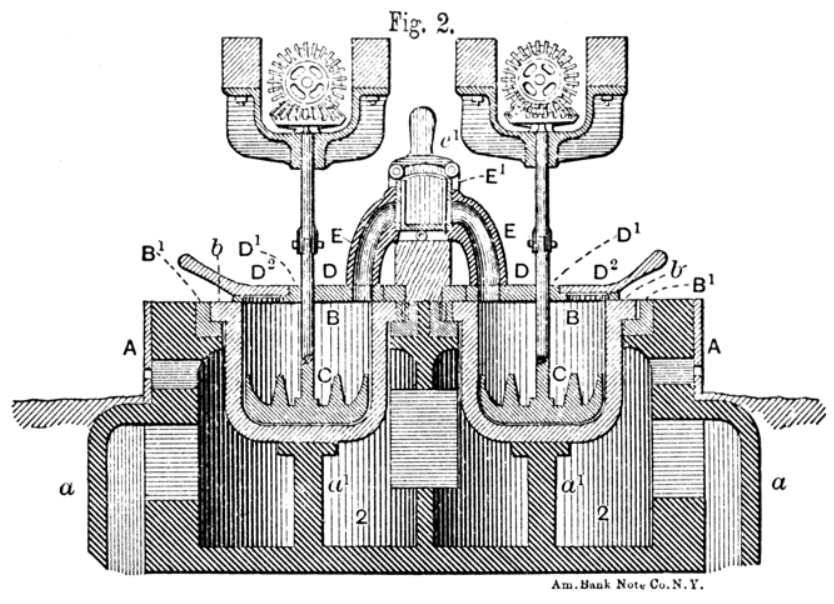

removed from the masonry and easily replaced. These retorts will last six weeks when in continuous operation. They are cast with the iron about one and one-fourth inch thick. Carhuff's revolving furnace marked an advance in the manufacture of ferrocyanide of potash and is the best method in use at the present time.

Figure I shows Carhuff's revolving furnace in part section and elevation, and Figure 2 shows Bower's melting pots in cross section. 